\title{
射出成形機における IT 化
}

\section{1.はじめに}

プラスチック射出成形加工のコスト削減を目的として， 作業記録の省力化, 検査工程の省力化, 成形システムの無 人化など目的に合わせた様々な管理システムが提案されて きた. 近年，コンピュータの進歩と共に，IT（情報技術） の発展によるコンピュータネットワークの進歩が, 成形機 をLAN やインターネットなどへ接続することを可能とし た。「ユビキタス」時代が到来し，成形工場の成形機，お よびその管理システムの IT 化を推進した.

当社も顧客ニーズに応えるため, 成形機, およびその管 理システムの高機能化・IT 化について様々な取り組みを してきた。成形管理システムと成形機制御装置の IT 化の 現状と特徴について，新たに機能を見直した品質・生産管 理システム NC-NET PQ と最新の制御装置 TACTを例に 報告する.

\section{2．成形情報管理システム}

品質管理に必要な成形条件，ショットモニタデータを収 集・管理するためには, 成形機制御装置とデー夕通信によ り接続した管理システムが必要である。当社は，1980 年 代初期，マイクロコンピュータを搭載した NC-8000 制御 装置を開発・上市するとともに成形管理システムの開発に も着手した。

$\mathrm{NC}-8000$ 搭載成形機 128 台とデータ通信回線で接続し, 群管理する NC-NET（NISSEI Controller Network）のシ ステム（図 1）をユーザに納入したことをはじめとし，以 後多くユーザへの納入実績をあげてきている.

通信回線については, 図 1 のような通信速度 $1200 \mathrm{bps,}$ 最大伝送距離 $500 \mathrm{~m}$ の $20 \mathrm{~mA}$ 電流ループ通信から更に信 頼性・通信速度を向上させた光ケーブルへと変更し，また， 開発効率とメンテナンス性向上のために, データ収集・帳 票出力部をパーソナルコンピュータ（以下, PC）に置き 換えることを実施してきた。

残された課題は次のようなものがあった.

(1)成形機が配置される工場と管理コンピュータを設置する 事務所間の通信でのデータ化けを防ぐため，ノイズに強

\footnotetext{
* Magario, Takashi

日精樹脂工業(株) 開発部制御開発課

長野県埴科郡坂城町南条 2110 ( ( 3 389-0693)

2003.9.19 受理
}

い専用通信線の配線が必要である.

(2)シリアル通信による通信速度に限界がある.

(3)当社がラインナップする汎用機をはじめ, ダブルイン ジェクション，竪型機などあらゆる特殊機で管理項目が 異なることによる通信プロトコルの統一が難しく，混在 管理ができない.

(4)ユーザの生産システムに合わせ，作りこむケースがほと んどで, 納入時におけるソフトウエア作成, 設置・調整, アフターフォローに多くの工数を必要とする.

\subsection{IT を取り込んだ NC-NET PQ}

昨年, 品質・生産管理システム NC-NET PQについて 見直しを行った. 20 年にわたり蓄積してきた成形管理シ ステムのノウハウを活かし，顧客が真に満足できる高機能 で使い易いシステムに見直しを行った．システムソフトウ エアはパッケージ化による低価格化を実現し, 汎用 OS で あるWindows 上で実行可能とした，構成を図 2 , 機能概 要は表 1 に示す.ITを取り込んだ特徴を以下にあげる.

1) LAN 接続による通信速度の向上

サーバと成形機を LANで接続する. LAN コネクタを 持たない従来成形機については，アダプタを追加すること により対応した. LAN 接続にすることにより以下の効果

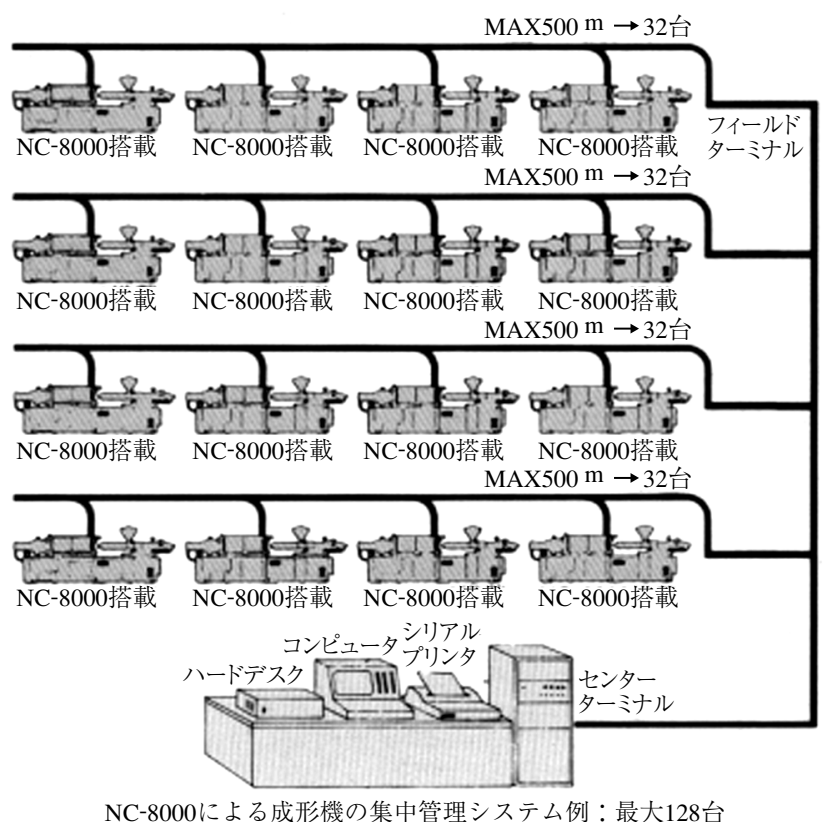

図 1 NC-8000 による集中監視システム 


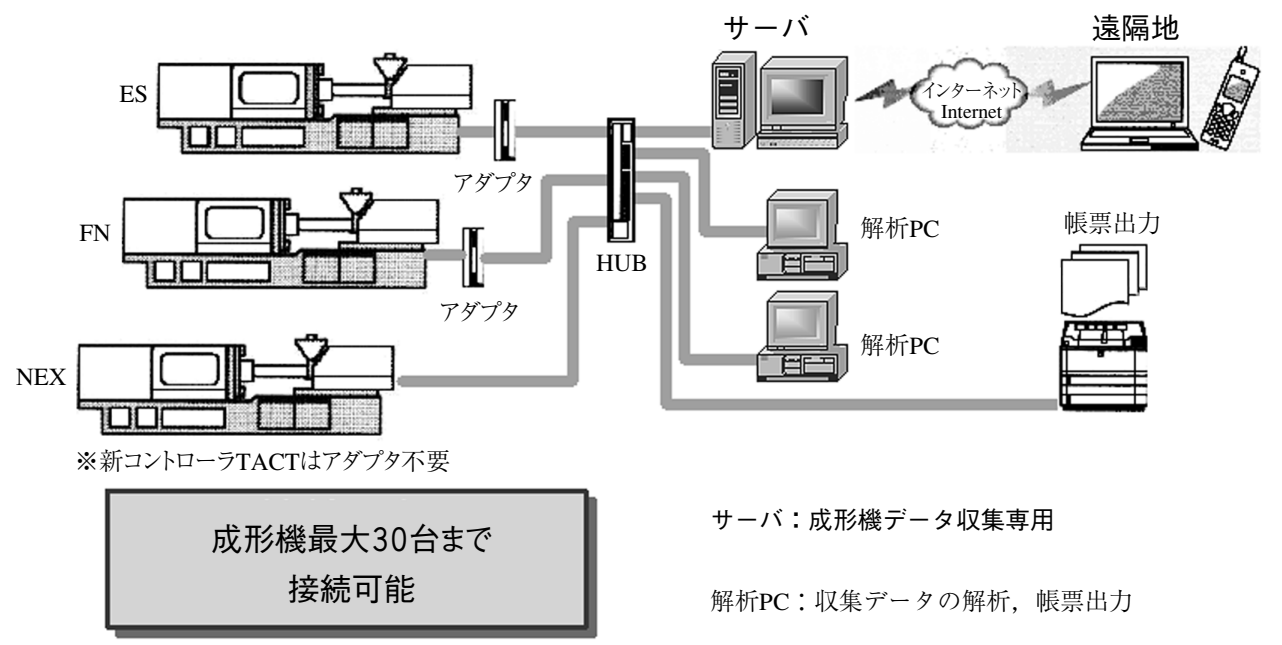

図 $2 \mathrm{NC}-\mathrm{NET} \mathrm{PQ}$ 構成

表 1 NC-NET PQ 機能

\begin{tabular}{|c|c|c|}
\hline 機能グループ & 能 & 概 \\
\hline 状態監視 & $\begin{array}{l}\text { 稼動状況 } \\
\text { 進渉状況 }\end{array}$ & $\begin{array}{l}\text { 工場レイアウトに合わせて成形機アイコンを配置 } \\
\text { サイクル, 達成率，稼動率とともに状態を色分け表示 } \\
\text { 生産状況を一覧表示 }\end{array}$ \\
\hline モニ夕監視 & $\begin{array}{l}\text { トレンドグラフ } \\
\text { トレンド数值 }\end{array}$ & $\begin{array}{l}\text { (1)指定した機械のモニタデータをトレンドグラフで表示 } \\
\text { (2)リアルタイム表示と実績データ後分析が可能 } \\
\text { (3)グラフの縦軸はショットまたは時間を指定可能 } \\
\text { (4)ヒストグラム, 相関図による分析も可能 } \\
\text { (1)指定した機械のモニタデータを数值表示 } \\
\text { (2)リアルタイム表示と実績データ後分析が可能 } \\
\text { (3)検索機能いよるデータの絞込みが可能 }\end{array}$ \\
\hline 稼動履歴管理 & $\begin{array}{l}\text { エラー履歴 } \\
\text { 成形条件変更管理 } \\
\text { 状態履歴 }\end{array}$ & $\begin{array}{l}\text { (1)成形機エラー履歴を管理 } \\
\text { (2)エラー集計上位 } 10 \text { 項目をパレート図表示 } \\
\text { (3)全成形機エラー発生度数と稼働率をグラフで一括表示 } \\
\text { 成形機の条件変更履歴を管理 } \\
\text { 成形機の自動/手動切替, 生産完了履歴を管理 }\end{array}$ \\
\hline 稼動状況管理 & $\begin{array}{l}\text { 稼動/停止グラフ } \\
\text { 稼動時間分析 }\end{array}$ & $\begin{array}{l}\text { 全成形機の稼動/停止状況を最大 } 1 \text { ケ月単位で一括表示 } \\
\text { 自動/手動/以上停止などの状態時間を積上げグラフ表示 }\end{array}$ \\
\hline 生産管理 & $\begin{array}{l}\text { 生産実績管理 } \\
\text { 生産予定数変更 }\end{array}$ & $\begin{array}{l}\text { 生産日報, 区間報（週報, 月報）出力 } \\
\text { 成形機生産予定数, 入り数をリモート変更可能（オプション） }\end{array}$ \\
\hline 成形条件管理 & $\begin{array}{l}\text { 成形条件表示 } \\
\text { 条件読出し } \\
\text { 成形条件設定 }\end{array}$ & $\begin{array}{l}\text { 成形機の成形条件を表示, サーバに保存 } \\
\text { サーバに保存した条件を表示 } \\
\text { サーバに保存した成形条件を成形機にリモート書込み }\end{array}$ \\
\hline E-mail 発信 & $\begin{array}{l}\text { イベントメール } \\
\text { 定期メール }\end{array}$ & $\begin{array}{l}\text { 指定イベント発生時, 指定エラー発生時, 生産完了時に発信 } \\
\text { 生産状況, 達成率など指定データを指定時刻に発信 }\end{array}$ \\
\hline Web 監視 & & 稼動状況，進渉状況，稼動履歴，生産実績，成形条件を遠隔監視 \\
\hline その他 & $\begin{array}{l}\text { バックアップ警報 } \\
\text { イベント警報音 } \\
\text { 帳票出力項目 } \\
\text { 取扱説明書 } \\
\text { 保護機能 } \\
\text { 対応言語 }\end{array}$ & $\begin{array}{l}\text { 指定日にサーバ蓄積データをバックアップするよう警報を発生 } \\
\text { 指定イベント発生時に, 警報音発生 } \\
\text { 各画面帳票出力, 出力帳票は ISO 対応可能 } \\
\text { Web ブラウザを用いて表示します } \\
\text { システムプロパティはシステム管理者だけが変更できるよう保護 } \\
\text { 日本語, 英語 }\end{array}$ \\
\hline
\end{tabular}

が生まれた。

(1)設置工事の簡略化一

ユーザ既設の PC およびネットワーク設備を解析 PC と

してそのまま利用できる. 成形機〜サーバ間とサーバ〜既 設ネットワーク間の配線工事のみが必要となる.
(2)通信データの大容量化

通信速度は 10/100 Mbps と, 多量のデー夕を高速で通 信できるようになった。

(3)システムの簡略化

複数の成形機とシリアルデー夕通信を行い, 成形機情報 
の収集・蓄積する役割を果たしていた専用コンピュータ （図 1）を汎用の PCサーバで構成でき，システムが簡略 化できた.

(4)LAN による通信プロトコルの統一

解析コンピュータのデータ処理方法を工夫するだけで, 当社が用意する多種多様のバリエーションの成形機の混在 が可能となった.

(5)遠隔地監視

インターネット網を利用した VPN (Virtual Private Network：インターネット（公衆網）をトンネリングと呼ば れる技術を使用して，簡単にしかも低価格でプライベート なセキュアネットワークを構築するサービス）を利用すれ ば，比較的安価にかつ容易に，海外工場などの遠隔接続，

リモートメンテナンスが行える。

(6)無線 LAN の応用

市販の無線 LAN を使用でき，成形機レイアウトの変更 を頻繁に行う場合や，クリーンルーム内など LAN 配線が 難しい場合に柔軟に対応できる。無線 LAN の用途は今後 広がると予想される。無線 LANアダプタの設置例を図 3 に示す．選定のポイントは以下に述べる.

・データ信頼性の問題一成形作業中, 成形機, 材料, 周辺 機器より発生するノイズに強い機器の選定を行った.

・接続の問題一Windows 用, Linux 用などの専用ドライバ を必要とせず，どんな機器でも無線 LAN 接続アダプタ に接続するだけで無線 LANへのアクセスが可能となる. ・設置の問題一アダプタは後付可能で, 且つアクセスポイ ントの設置場所に合わせて設置可能である．写真のアダ プタは本体に取り付けられた磁石により, 成形機に取り 付けている。 また，アダプタ電源は LAN ケーブルより 供給可能である。専用電源ラインを用意する必要がなく, 設置は簡単である.

・輸出の問題一各国電波法の違いにより国ごとに対応が必 要である.それぞれの国の電波法に対応する無線 LAN アダプタを供給しているメーカもあるが, 対応できる国 は少ない. 現在, 当社で使用しているものは, 北米およ びアジアで使用できる.

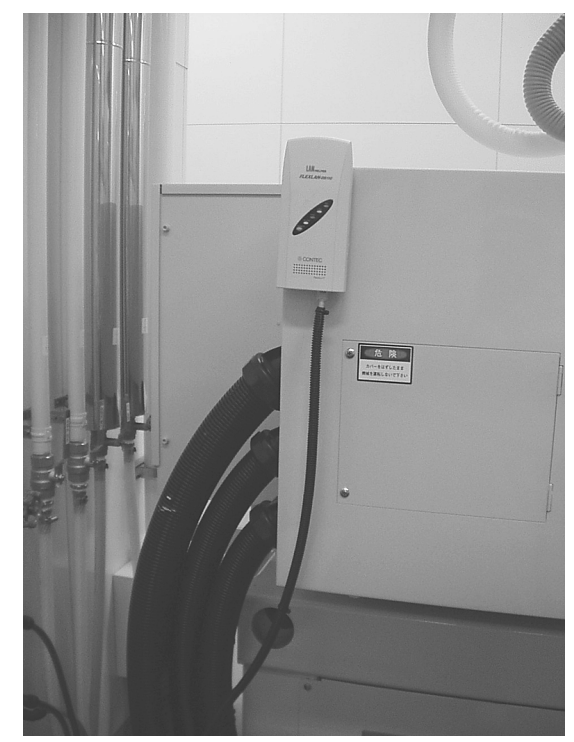

図 3 無線 LAN アダプタ設置例
無線 LAN 設置の場合, 設置場所, 周囲機器環境により, 電波環境が大きく影響される場合がある。機器の配置につ いて現地で調整しながら設置する必要がある.

2) Web 監視機能

インターネットを利用した情報伝達も重要な機能である. NC-NET PQのサーバは, Web サーバとして機能し, イ ンターネットやイントラネットを通じ, 稼動状況, 進渉度 状況, 生産実績, 成形条件を遠隔地の PC から監視可能と した（図 4).

Web サーバ機能は，Windows 標準装備の IIS (インター ネット・インフォメーション・サービス)，またはフリー ソフトウエア Apache などを使って簡単に構築可能である. 3) メール通知機能

E-mail は，Web 監視と異なりセキュリティ管理面でも メリットがあり有効である．今や企業内では標準的な通信 手段として使われている，NC-NET PQでは，成形機の 稼動・停止，生産完了時などに発信するイベントメール機 能と生産数量などの進渉情報を指定時刻に発信する定期 メール機能に応用している.メールは携帯電話で受信して も見やすいようレイアウトされている，必要な情報が必要 な時に E-mail で自動発信されるため，忙しい管理者に とって, 携帯電話への E-mail として使えば, 情報の取り こぼしは最小限に抑えることができる。

\section{4 ）英文対応}

標準パッケージに日本語版・英語版の両システムをバイ ンドしている.インストール時に PCの OS 対応言語にあ わせ選択が可能である.

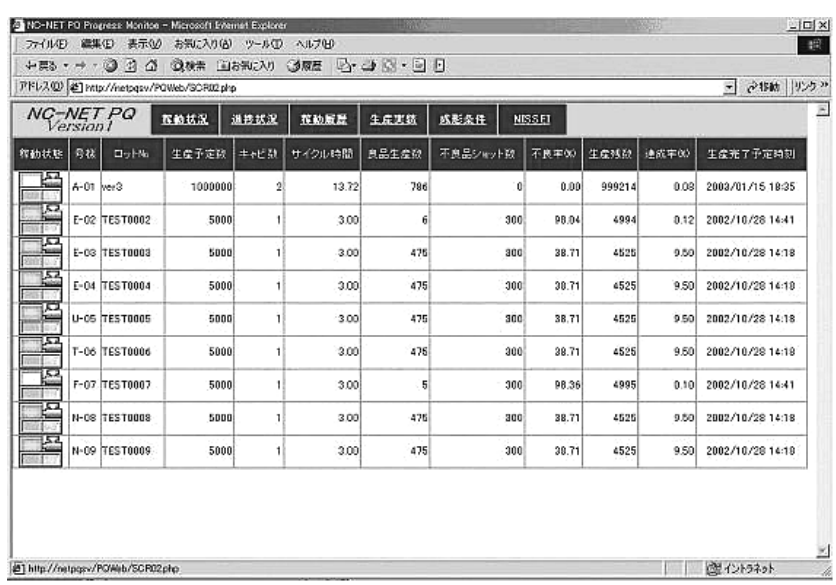

図 4 Web による進渉度監視例

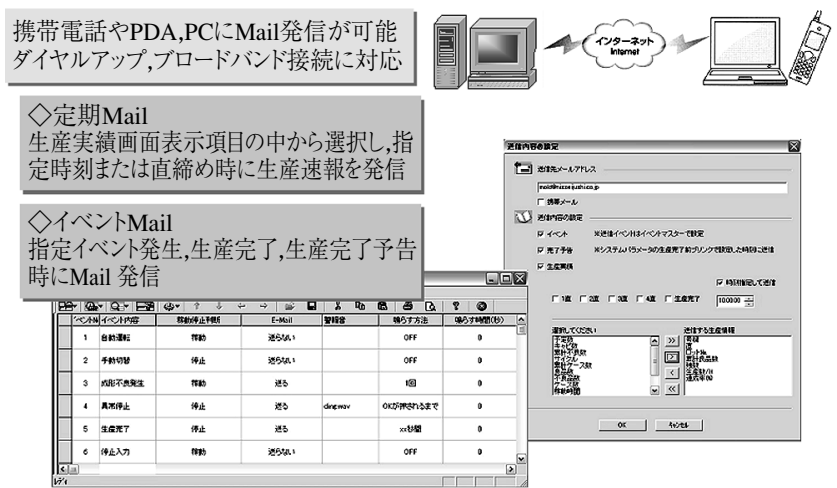

図 5 E-mail 発信機能 
当社顧客は海外展開をしている場合が多く，海外でも利 用可能なパッケージを用意した。海外の NC-NET PQ シ ステムの状況を，インターネットを通じて日本から監視す ることも可能である.

5 ）テキストファイル管理

汎用データベースシステムを利用せず，収集データはテ キスト形式で保存した. テキストデータは, 特別な処理を 加えなくても，異機種コンピュータまたは別システム間の デー夕交換が自由にできる。また, Excel, Accessなど市 販のアプリケーションソフトで, 自社のスタイルに合った 帳票出力が簡単に行える. 既存のシステムと LAN で接続 可能であれば専用システムを造りこむことなく連携できる.

\section{3 . 制御装置の発展}

成形情報管理システムの発展とともに成形機制御装置の IT 化も進んでいる。当社は業界初のマイコン搭載制御装 置 NC-8000を実用化後も制御装置の高機能化に取り組み 続け, NC-8300, NC 9000, NC 9300 シリーズを送り出し てきた。当社は今年 6 月より新型電気式成形機 NEX シ リーズを上市した.NEX には,射出スキャニング時間 $100 \mu$ 秒（1万分の 1 秒）の性能を持ち成形安定性に優れた新制 御装置『TACT』(図 6) を装備している.

\section{1 新制御装置 TACT}

最近では, 成形機を高精度に制御する事に加え IT 機能 も重要な項目として求められるようになった。

TACT は，従来の NC $9300 \mathrm{~T}$ の機能を継承しながら， 制御性・拡張性・機能の向上と使いやすさを追求した新制 御装置である. 主な特徵は，表 2 に示すとおりである.

TACT は，12.1 インチカラー液晶タッチパネルを装備 し，より扱いやすく見やすくなった. 外部とのインター
フェース用に, LAN・USB コネクタを標準装備している. USB コネクタにはプリンタまたはコンパクトフラッシュ メモリ（以下，CF）を接続できる，CF は成形条件デー夕， ショットモニタデータなどを保管する外部メモリとして利 用できる．ネットワーク接続した PC 上に指定された共有 フォルダは, TACT と LAN 接続することで TACT から は CF 代わりの外部メモリとして利用することができ，次 の利点がある.

・ショットモニタは, PC 上で Excel などによりデータの 推移をオンラインで確認する事が可能となる.

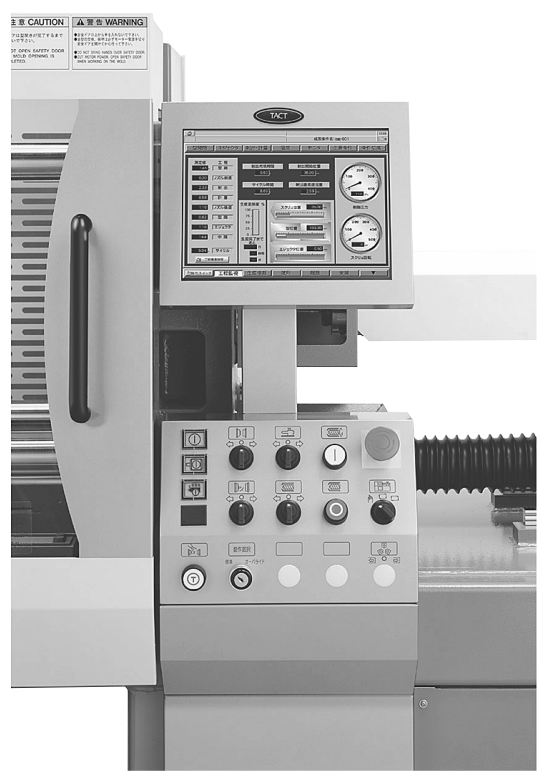

図 6 TACT 外観図

表 2 新コントローラ TACT の主な特徴

\begin{tabular}{|c|c|}
\hline 射出 $100 \mu$ 秒の高速制御 & $\begin{array}{l}\text { ○再現性・安定性の向上 } \\
\text { ○高速充填時におけるVP 切換時制御向上 }\end{array}$ \\
\hline $\begin{array}{l}\text { 成形を考えた多彩な } \\
\text { プログラムを標準装備 }\end{array}$ & 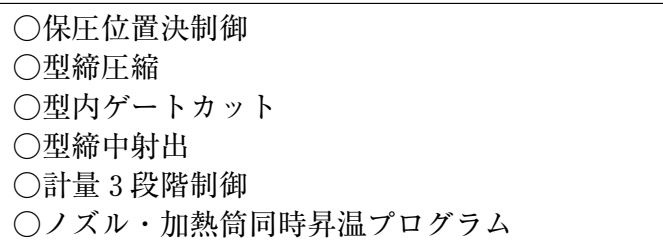 \\
\hline 品質管理の強化 & $\begin{array}{l}\bigcirc 23 \text { 項目のショットモニタデータ } \\
\text { ○全モニタ項目を良否判別モニタとして使用可能 } \\
\text { ○過去のショット指定範囲を統計処理した結果を } \\
\text { 良否判別条件に入力可能 }\end{array}$ \\
\hline $\begin{array}{l}\text { ラダー言語によるプログ } \\
\text { ラミング機能 }\end{array}$ & 入出力各 4 点を使用して自由にプログラミング \\
\hline LAN コネクタ標準装備 & NCNET PQ, DLA, 外部 PC との接続が容易 \\
\hline USB 1.1 ポート & プリンタおよび外部記憶装置を接続 \\
\hline ブラウザ機能 & 作業標準書・樹脂データなどをブラウザ表示 \\
\hline その他 & $\begin{array}{l}\text { ○サーボモータ負荷監視機能 } \\
\text { 高精度な金型保謢 } \\
\text { ○保存された成形条件のプレビュー } \\
\text { ○射出・型スペック表示 } \\
\text { ○内部メモリ最大 } 300 \text { 条件保存 } \\
\text { ○12.1インチワイド液晶画面・チルト方式採用 } \\
\text { ○操作性を重視したセレクタースイッチ }\end{array}$ \\
\hline
\end{tabular}




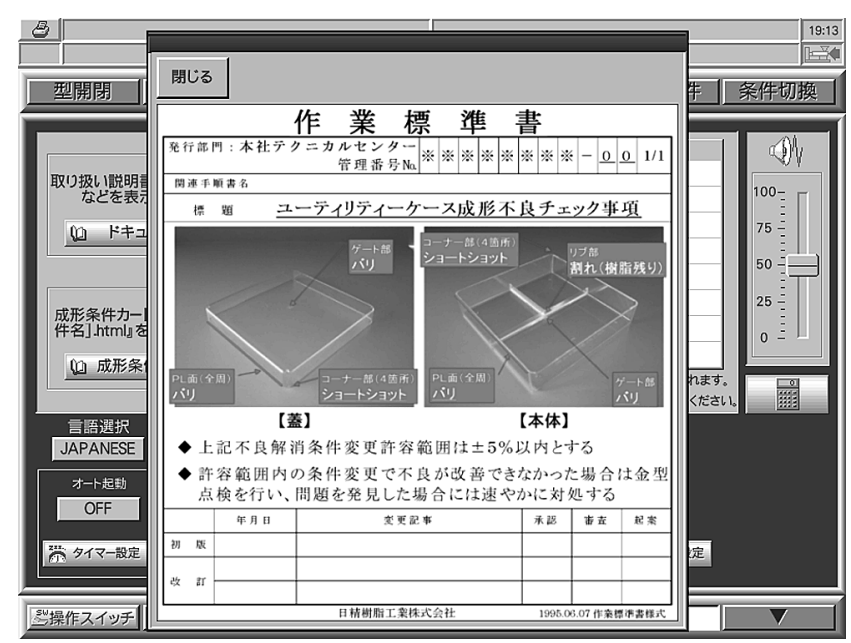

図 7 作業標準書表示例

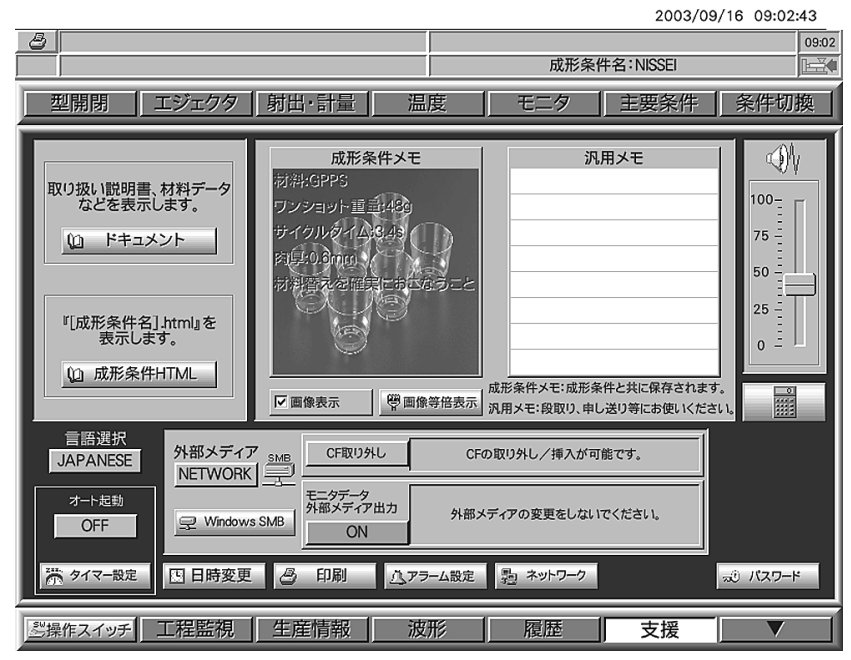

図 8 成形条件メモ表示例

・成形条件データは，PCに接続された他の成形機と共有 できる。また, Excel 等を用いてデータの内容が PC 上 で確認できる。

・NC-NET PQ が収集した成形条件データを，TACT 画 面上で読み込み操作ができる.

NC-NET PQ とはアダプタを経由することなくLAN に 直結できる。また，成形計測システム DLA とも LAN 接 続でき，波形デー夕を含めた DLA の解析対象デー夕の全 ては，LAN 経由で TACT から発信される．以上の様に， TACTにLAN コネクタを標準装備した事で, NC-NET $\mathrm{PQ}, \mathrm{PC}, \mathrm{DLA}$ といった外部ネットワークシステムとの 接続が非常に簡単となった。

画像デー夕表示機能も充実した。 USBに接続した CF, またはネットワーク接続した PCに保存している成形条件 と, その成形品に関連する画像情報（図 7）を読み込んで

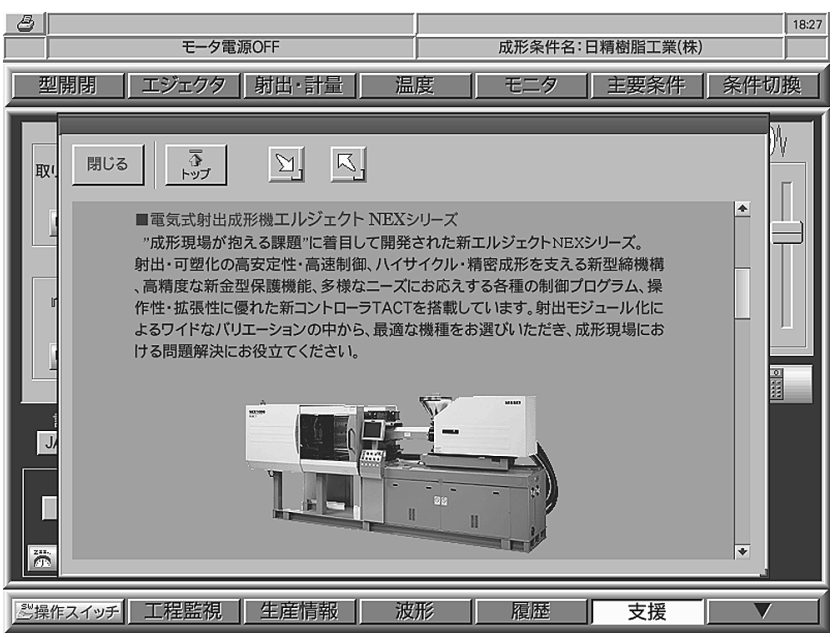

図 9 ブラウザ表示例

画面上に表示させることができる．眓 8 のように，画面上 に表示された画像情報の上に，TACT 上でテキスト入力 した文字を重ねて表示することが可能である。この機能に より, 次の成形担当者に成形上の留意点を申し送ることも できる。な拝，画像データはビットマップまたは JPEG が 使用できる.

TACT にはブラウザ機能が装備されている．作業標準 書，樹脂データベース等を HTML 形式で作成して CF に 保存しておけば，TACTで読み达み表示できる。図 9 は 当社ホームページデータを CF にダウンロードして表示さ せた例である. HTML ファイルは，テキストファイルと 同様どんなコンピュータでも表示・作成編集可能である.

\section{4.おわりに}

インターネット普及などIT の進歩で，成形機および周 辺機器は, 遠隔地からの監視やリモートメンテナンスも実 現可能となった.

重要な情報がネットワークを通じて飛び交うことによる セキュリティ確保は重要であり，外部からの不正な妨害か ら守れる適切なシステム管理が要求される。管理者は膨大 な情報を収集・分析できるようになった反面，適切な情報 の選別・状況分析が重要なキーポイントとなり，対応を間 違うと大きなダメージを負うリスクも増大している.

発展を続ける高度情報処理技術を上手に使いこなして行 くためには，自社の作業を十分に分析・把握した上で，必 要性・目的を明確にしたシステム構築がキーポイントとな る.『成形現場を中心とした』考え方に立って導入してい くことが適切なシステムを構成するためにも，運用して行 く上にも，最も大切なことである. 